\title{
Purification and Some Properties of Thiamine-Binding Protein from Rice Bran
}

\author{
Hiroshi Nishimura, ${ }^{1}$ Yasuo Uehara, ${ }^{2}$ Kenji Sempuku, ${ }^{1}$ \\ and Akio IWASHIMA ${ }^{1}$ \\ ${ }^{1}$ Department of Biochemistry and ${ }^{2}$ Department of Surgery, \\ Kyoto Prefectural University of Medicine, \\ Kamikyo-ku, Kyoto 602, Japan \\ (Received July 15, 1983)
}

\begin{abstract}
Summary A thiamine-binding protein was purified from the extract of rice bran acetone powder by conventional procedures of acid precipitation, a series of column chromatography on DEAE-Sephadex A-50 and DEAE-cellulose, and gel filtration of Sephadex G-200. The purified thiamine-binding protein was nearly homogeneous as judged by disc gel electrophoresis and the molecular weight was estimated to be 94,000 by gel filtration on Sephadex G-200 and 50,000 by sodium dodecylsulfate (SDS) gel electrophoresis, suggesting that the protein is composed of two identical subunits. The apparent $K_{\mathrm{d}}$ and $B_{\max }$ of the binding for $\left[{ }^{14} \mathrm{C}\right]$ thiamine was $0.44 \pm 0.05 \mu \mathrm{M}$ and $17.2 \pm 0.7 \mathrm{nmol} / \mathrm{mg}$ of protein, respectively. The optimal $\mathrm{pH}$ for the binding is between 8.0 and 9.0. From the competition experiment using several thiamine derivatives, high binding specificity of the protein for thiamine was presumed.

Key Words thiamine-binding protein, molecular weight determination, $\mathrm{pH}$ optimum, rice bran
\end{abstract}

Thiamine-binding proteins are widely distributed among various organisms. In microorganisms they have been found in Escherichia coli(1-3), Lactobacillus casei (4) and Saccharomyces cerevisiae $(5,6)$. The exact function of these thiaminebinding proteins in microorganisms is still unknown, however, evidence for their involvement in thiamine transport has been discussed (7). Recently, some thiaminebinding proteins have been found in animal tissues such as chicken egg white (8) and liver (9), and it has been supposed that the binding protein in chicken egg white has a role in the deposition and transport of thiamine for the proper growth and development of chick embryo. On the other hand, a previous communication from this laboratory has indicated that there exists a thiamine-binding protein in rice bran, which was the first observation made on a plant(10). In this paper we

\footnotetext{
${ }^{1}$ 西村 洋, 上原泰夫, 仙福健治, 岩島昭夫
} 
describe the purification and characterization of the thiamine-binding protein from rice bran.

\section{MATERIALS AND METHODS}

Chemicals. $\quad\left[{ }^{14} \mathrm{C}\right]$ Thiamine ([thiazole-2- $\left.{ }^{14} \mathrm{C}\right]$ thiamine hydrochloride, 24.3 $\mathrm{mCi} / \mathrm{mmol}$ ) was obtained from the Radiochemical Centre, England. Pyrithiamine hydrobromide, oxythiamine hydrochloride, thiamine monophosphate chloride and thiamine pyrophosphate chloride were the products of Sigma Chemical Co. Thiamine hydrochloride was purchased from Nakarai Chemicals Ltd. (Kyoto). Chloroethylthiamine (3-2'-methyl-4'-aminopyrimidyl-(5')-methyl-4-methyl-5-chloroethyl thiazolium chloride hydrochloride) was a gift from Sankyo Co., Ltd. (Tokyo) and $O$-benzoylthiamine disulfide from Tanabe Chemical Industries Ltd. (Osaka). Dimethialium (3-2'-methyl-4'-aminopyrimidyl-(5')-methyl-4,5-dimethyl thiazolium chloride hydrochloride), northiamine (3-2'-methyl-4'-aminopyrimidyl4-methyl-5-hydroxyethyl thiazolium chloride hydrochloride), hydroxyethylthiamine, 2-methyl-4-amino-5-hydroxymethyl pyrimidine and 5-(2-hydroxyethyl-4methyl)thiazole were gifts from Takeda Chemical Industries Ltd. (Osaka). $\left[{ }^{14} \mathrm{C}\right]-$ Thiamine monophosphate and $\left[{ }^{14} \mathrm{C}\right]$ thiamine pyrophosphate were synthesized from $\left[{ }^{14} \mathrm{C}\right]$ thiamine $(24.3 \mathrm{mCi} / \mathrm{mmol})$ by a method previously described $(11)$. The radiochemical purities of $\left[{ }^{14} \mathrm{C}\right]$ thiamine monophosphate and $\left[{ }^{14} \mathrm{C}\right]$ thiamine pyrophosphate as found by paper chromatography in isopropanol- $0.5 \mathrm{M}$ sodium acetate buffer ( $\mathrm{pH} 4.5$ )-water $(65: 15: 20)$ were $96.7 \%$ and $96.1 \%$, respectively. All other chemicals were purchased from commercial suppliers.

Assay of thiamine-binding. Unless otherwise indicated, the binding activity was assessed by an equilibrium dialysis experiment for $24 \mathrm{~h}$ at $4^{\circ} \mathrm{C}$ as previously described (12), except for the use of $\left[{ }^{14} \mathrm{C}\right]$ thiamine at a final concentration of $1 \mu \mathrm{M}$ $(\mathrm{pH} 7.5)$. The activity measured by this method was proportional to the amount of protein used in this experiment.

Purification of binding protein. Unless otherwise indicated, all the operations were conducted at $4{ }^{\circ} \mathrm{C}$. One hundred grams of fresh acetone powder of commercially available rice bran were suspended in 1 liter of $0.05 \mathrm{M}$ potassium phosphate buffer, $\mathrm{pH}$ 7.5. After stirring for $3 \mathrm{~h}$, the suspension was centrifuged at $11,000 \times g$ for $15 \mathrm{~min}$ and the supernatant was adjusted to $\mathrm{pH} 6.0$ by $5 \mathrm{~m}$ acetic acid. The precipitate was dissolved in $330 \mathrm{ml}$ of $0.05 \mathrm{M}$ potassium phosphate buffer, $\mathrm{pH}$ 7.0 , and then added to about $15 \mathrm{~g}$ of DEAE-Sephadex A-50 equilibrated with the same buffer, followed by stirring for $1 \mathrm{~h}$ at $0^{\circ} \mathrm{C}$. This mixture was set to a column $(3.7 \times 50 \mathrm{~cm})$, washed with $500 \mathrm{ml}$ of $0.05 \mathrm{M}$ potassium phosphate buffer, $\mathrm{pH} 7.0$, and eluted by an increasing linear gradient of $\mathrm{KCl}$ concentration to $0.3 \mathrm{M}$. The thiamine-binding protein was eluted around $0.27 \mathrm{M}$. The active fractions were combined and diluted 5 times with $0.05 \mathrm{M}$ potassium phosphate buffer, $\mathrm{pH} 7.0$. The diluted solution was applied to a column $(3.0 \times 22 \mathrm{~cm})$ of DEAE-cellulose equilibrated with the same buffer. The active fractions eluted around $0.16 \mathrm{M} \mathrm{KCl}$ by an 
increasing linear gradient of $\mathrm{KCl}$ concentration to $0.3 \mathrm{M}$ were combined, concentrated by using an XM50 Amicon ultrafilter and then applied to a Sephadex G200 column $(20 \times 90 \mathrm{~cm})$ equilibrated with $0.05 \mathrm{M}$ potassium phosphate buffer, $\mathrm{pH}$ 7.5 , containing $0.1 \mathrm{M} \mathrm{KCl}$ and eluted with the same buffer.

Estimation of molecular weight. The molecular weight of the purified binding protein was estimated by gel filtration on a Sephadex G-200 column $(1.5 \times 70 \mathrm{~cm})$ according to Andrews (13) using $0.05 \mathrm{~m}$ potassium phosphate buffer, $\mathrm{pH} 7.5$,

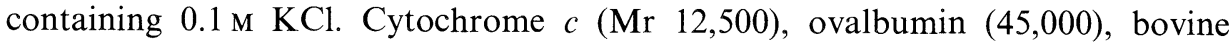
serum albumin $(68,000)$ and aldolase $(158,000)$ served as protein markers. SDSpolyacrylamide gel electrophoresis as described by Weber and Osborn (14) was also used for the estimation of subunit molecular weight. Escherichia coli RNA polymerase [ $\alpha$-subunit $(\operatorname{Mr} 39,000), \beta$-subunit $(155,000)$ and $\beta^{\prime}$-subunit $(165,000)$ ], bovine serum alubmin $(68,000)$ were used as the standard protein markers.

Disc gel electrophoresis. Analytical polyacrylamide gel electrophoresis was carried out using $7 \%$ acrylamide at $\mathrm{pH} 9.5$. The sample was run at $7.0 \mathrm{~mA}$ per tube for $1 \mathrm{~h}$ at room temperature. The protein was detected by staining with Coomassie brilliant blue. The binding activity of the thiamine-binding protein during polyacrylamide gel electrophoresis was detected as previously described (6).

Determination of optimum $\mathrm{pH}$ and $K_{\mathrm{d}}$ value. The effect of $\mathrm{pH}$ on the binding activity was investigated by the same procedure as described in the binding assay, except for the use of $0.05 \mathrm{~m}$ potassium phosphate buffer ( $\mathrm{pH} 5.0-9.2), 50 \mathrm{~mm}$ Tris$\mathrm{HCl}$ buffer ( $\mathrm{pH} 7.5-9.5)$ and $0.05 \mathrm{M} \mathrm{NaHCO}-\mathrm{Na}_{2} \mathrm{CO}_{3}$ buffer (pH 9.5-10.5). To determine the $K_{\mathrm{d}}$ and $B_{\max }$ values for thiamine, the binding activity was assayed by an equilibrium dialysis experiment at room temperature for $24 \mathrm{~h}$ in $0.05 \mathrm{~m}$ potassium phosphate buffer ( $\mathrm{pH} 7.5$ ) containing 0.1 to $2 \mu \mathrm{M}$ thiamine.

Effect of inhibitors on binding activity. Each thiamine derivative and analog was added to the dialyzing buffer simultaneously with $1 \mu \mathrm{M}\left[{ }^{14} \mathrm{C}\right]$ thiamine at the concentration of $10 \mu \mathrm{M}$, and then the thiamine-binding activity was assayed as described above.

Determination of protein. Protein was determined by the method of Lowry et al.(15) with albumin as a standard.

\section{RESULTS}

\section{Purification of thiamine-binding protein from rice bran}

The results of the purification of thiamine-binding protein from rice bran acetone powder are summarized in Table 1. The binding activity eluted from Sephadex G-200 coincided as a whole with a protein profile as shown in Fig. 1. The thiamine-binding protein was purified about 42 -fold from the crude extract of rice bran acetone powder with a recovery of $13 \%$. Disc gel electrophoresis at $\mathrm{pH} 9.5 \mathrm{of}$ a purified thiamine-binding protein revealed a broad single band (Fig. 2a) and the location of binding activity toward thiamine coincided with the stained part of the gel in duplicate runs of the purified protein (data not shown). But this purified

Vol. 30, No. 1, 1984 
Table 1. Purification of thiamine-binding protein from rice bran.

\begin{tabular}{lrccr}
\hline \multicolumn{1}{c}{ Step } & $\begin{array}{c}\text { Total } \\
\text { protein } \\
(\mathrm{mg})\end{array}$ & $\begin{array}{c}\text { Total activity } \\
\text { (nmol thiamine- } \\
\text { binding) }\end{array}$ & $\begin{array}{c}\text { Specific activity } \\
\text { (nmol thiamine } \\
\text { bound/mg } \\
\text { of protein) }\end{array}$ & $(\%)$ \\
\hline 1. Crude extract & 6,843 & 1,740 & 0.26 & 100 \\
2. Acid precipitation & 1,863 & 1,630 & 0.88 & 94 \\
3. DEAE-Sephadex A-50 & 102 & 660 & 6.46 & 38 \\
4. DEAE-cellulose & 45 & 410 & 9.05 & 24 \\
5. Gel filtration on & 21 & 220 & 10.62 & 13 \\
Sephadex G-200 & & & & \\
\hline
\end{tabular}

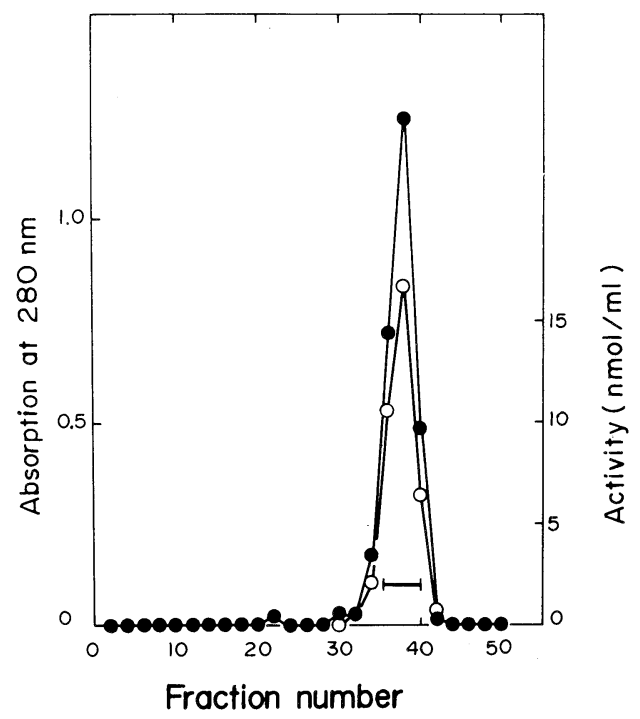

Fig. 1. Gel filtration on Sephadex G-200 of thiamine-binding protein from rice bran. $\bigcirc$, thiamine-binding activity; $\bullet$, absorbance at $280 \mathrm{~nm}$. The horizontal bar represents the fractions pooled.

preparation still contained a small amount of minor protein component $(\mathrm{Mr} 33,000$ 35,000) detectable by SDS gel electrophoresis (Fig. 2b). This minor protein component (Mr 33,000-35,000) appeared to be produced by partial proteolysis of the major component ( $\mathrm{Mr} 50,000)$, since it was formed from the major component by a limited proteolysis with trypsin (unpublished observation). The thiaminebinding protein did not appear to be a glycoprotein since it was unstainable using the periodic acid-Schiff base (PAS) staining method.

\section{Molecular weight of thiamine-binding protein}

As shown in Fig. 3A, the molecular weight was estimated to be about 94,000 by 


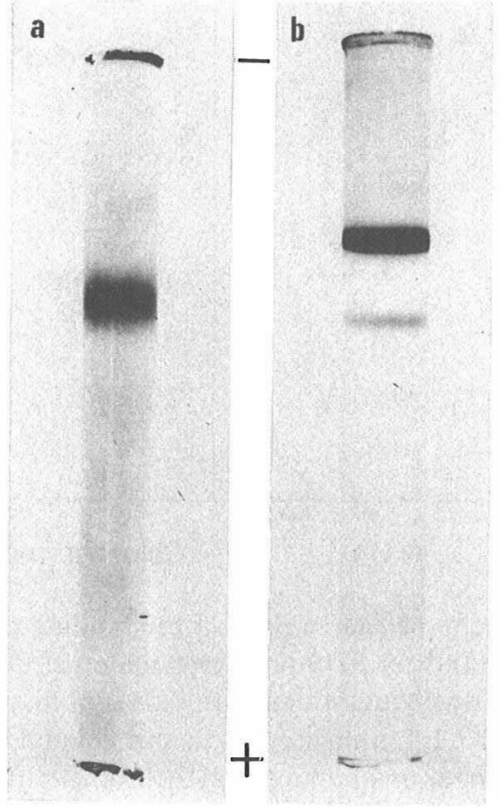

Fig. 2. Polyacrylamide gel (a) and SDS-polyacrylamide gel (b) electrophoresis of the purified thiamine-binding protein from rice bran. The gel was stained for protein with Coomassie brilliant blue R250.

gel filtration on Sephadex G-200 and to be approximately 50,000 by SDS gel electrophoresis (Fig. 3B). These results suggested that the thiamine-binding protein of rice bran was composed of two identical subunits.

\section{Effect of $\mathrm{pH}$ on thiamine-binding protein}

As shown in Fig. 4, the binding activity of the thiamine-binding protein at various $\mathrm{pH}$ values indicates that the $\mathrm{pH}$ optimum is $8.0-9.0$.

\section{Effect of ligand concentration on the binding activity}

The effect of various thiamine concentrations on the binding equilibria was studied using $\left[{ }^{14} \mathrm{C}\right]$ thiamine. The apparent dissociation $\left(K_{\mathrm{d}}\right)$ and maximum bound $\left(B_{\max }\right)$ for the ligand were calculated from the Hughes-Klotz plot as shown in Fig. 5. The plots for the ligand showed a linear relationship and the value for apparent $K_{\mathrm{d}}$ was $0.44 \pm 0.05 \mu \mathrm{M}$ and that of $B_{\max }$ was $17.2 \pm 0.7 \mathrm{nmol} / \mathrm{mg}$ of protein.

\section{Effect of thiamine derivatives and analogs on the binding activity}

The competition of several thiamine drivatives and analogs with thiamine for binding is illustrated in Table 2. The results show that only chloroethylthiamine is an effective inhibitor to the same degree as nonlabeled thiamine for the binding of $\left[{ }^{14} \mathrm{C}\right]$ thiamine, but that thiamine antagonists such as pyrithiamine, dimethialium, 


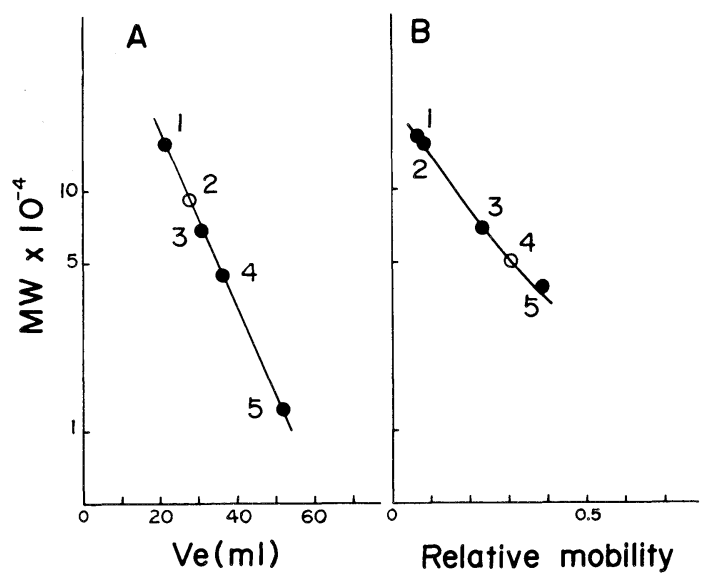

Fig. 3. Estimation of the molecular weight of the binding protein by gel filtration on Sephadex G-200 (A) and by SDS-polyacrylamide gel electrophoresis (B). A. The column $(1.5 \times 70 \mathrm{~cm})$ was equilibrated with $0.05 \mathrm{M}$ potassium phosphate buffer, $\mathrm{pH}$ 7.5 , containing $0.1 \mathrm{M} \mathrm{KCl}$. 1, aldolase; 2, thiamine-binding protein from rice bran; 3 , bovine serum albumin; 4 , ovalbumin; 5 , cytochrome $c$. B. $1 ; 2$ and 5 are the $\beta^{\prime}-, \beta$ and $\alpha$-subunit of RNA polymerase from Escherichia coli, respectively; 3 , bovine serum albumin; 4 , thiamine-binding protein from rice bran.

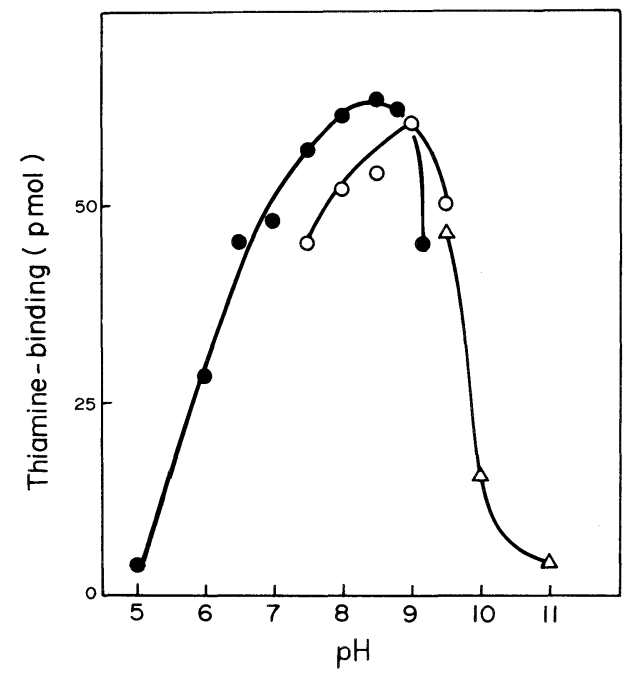

Fig. 4. Effect of $\mathrm{pH}$ on activity of the thiamine-binding protein from rice bran. $0.05 \mathrm{M}$ potassium phosphate buffer; $\bigcirc, 50 \mathrm{mM}$ Tris-HCl buffer; $\triangle, 0.05 \mathrm{M} \mathrm{NaHCO}_{3}$ $\mathrm{Na}_{2} \mathrm{CO}_{3}$ buffer. Each value is the average of duplicate determinations.

oxythiamine and northiamine were much less inhibitory on the binding of the protein to $\left[{ }^{14} \mathrm{C}\right]$ thiamine. The binding was not inhibited by $O$-benzoyl thiamine 


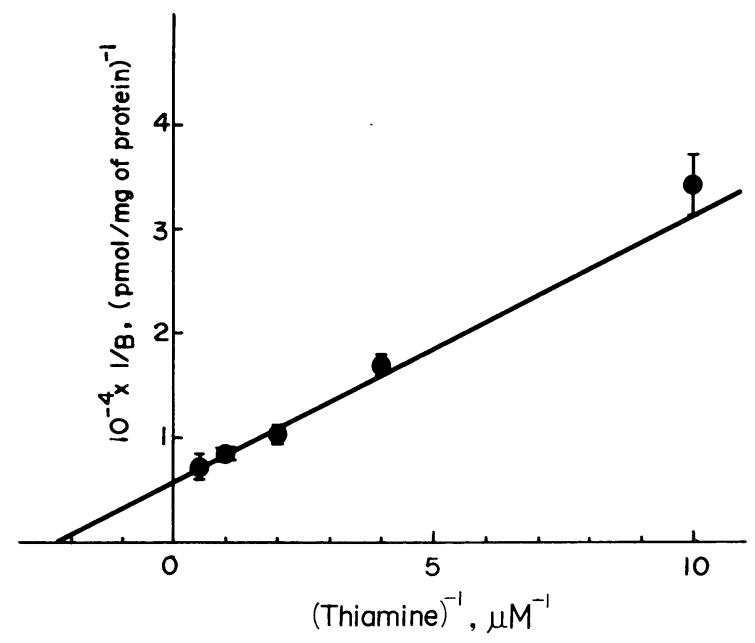

Fig. 5. Effect of thiamine concentration on the binding activity. Each point represents the mean $\pm \mathrm{SE}$ of triplicate determinations. Kinetic parameter $K_{\mathrm{d}}$ and $B_{\max }$ were determined using weighted fits of Hughes-Klotz plots, with the individual mean rates of triplicate experiments weighted by the factor $\mathrm{B}^{4} /(\mathrm{SE})^{2}$; the standard errors for $K_{\mathrm{d}}$ and $B_{\max }$ were calculated as described by Wilkinson (18). The values of these parameters were expressed as the mean $\pm \mathrm{SE}$.

Table 2. Effect of thiamine derivatives and analogs on binding of thiamine to rice bran thiamine-binding protein.

Each value is the average of duplicate determinations.

\begin{tabular}{|c|c|c|c|}
\hline \multirow{2}{*}{ Addition } & \multirow{2}{*}{$\begin{array}{l}\text { Molar ratio to } \\
{\left[{ }^{14} \mathrm{C}\right] \text { thiamine }}\end{array}$} & \multicolumn{2}{|c|}{$\left[{ }^{14} \mathrm{C}\right]$ Thiamine binding $(\%)$} \\
\hline & & Expt. 1 & Expt. 2 \\
\hline None & 0 & 100 & 100 \\
\hline Thiamine & 10 & 15.5 & 13.4 \\
\hline Chloroethylthiamine & 10 & 14.1 & \\
\hline Dimethialium & 10 & 60.5 & \\
\hline Hydroxyethylthiamine & 10 & 98.5 & \\
\hline Pyrithiamine & 10 & 78.1 & \\
\hline Oxythiamine & 10 & & 70.7 \\
\hline Northiamine & 10 & & 50.6 \\
\hline $\begin{array}{l}\text { 2-Methyl-4-amino-5-hydroxymethyl } \\
\text { pyrimidine }\end{array}$ & 10 & & 93.5 \\
\hline $\begin{array}{l}\text { 5-(2-Hydroxyethyl-4-methyl)- } \\
\text { thiazole }\end{array}$ & 10 & & 94.9 \\
\hline
\end{tabular}


disulfide, hydroxyethylthiamine, 5-(2-hydroxyethyl-4-methyl)thiazol or 2-methyl-4amino-5-hydroxymethyl pyrimidine.

Binding of $\left[{ }^{14} C\right]$ thiamine phosphates to rice bran thiamine-binding protein

Since thiamine phosphates such as thiamine monophosphate and thiamine pyrophosphate did not significantly inhibit the binding of $\left[{ }^{14} \mathrm{C}\right]$ thiamine to crude thiamine-binding protein from rice bran (10), the binding of ${ }^{14} \mathrm{C}$-labeled thiamine phosphates synthesized from $\left[{ }^{14} \mathrm{C}\right]$ thiamine to the purified thiamine-binding protein was examined. As shown in Table 3, the affinity of $\left[{ }^{14} \mathrm{C}\right]$ thiamine monophosphate and $\left[{ }^{14} \mathrm{C}\right]$ thiamine pyrophosphate to rice bran thiamine-binding protein was negligibly small.

\section{DISCUSSION}

Although the occurrence of thiamine-binding proteins in animal and microbial sources has been known for recent years, there has been no information forthcoming on purification of thiamine-binding protein from plants. In this study, a thiamine-binding protein was purified from rice bran in an almost homogeneous state. Thiamine-binding proteins thus far isolated from various sources have been found to have different molecular weights, i.e., 39,000 from Escherichia coli $(16,17)$, 140,000 from Saccharomyces cerevisiae (5) and 38,000 from egg yolk (8), but all of them are reported to be a single polypeptide. It is of interest to note that the molecular weight of the rice bran thiamine-binding protein was estimated to be 94,000 by gel filtration on Sephadex G-200 and to be 50,000 by SDS gel electrophoresis, indicating that the binding protein is composed of two identical subunits.

The $K_{\mathrm{d}}$ and $B_{\max }$ values of the thiamine-binding protein from rice bran were calculated to be $0.44 \pm 0.05 \mu \mathrm{M}$ and $17.2 \pm 0.7 \mathrm{nmol} / \mathrm{mg}$ of protein, respectively. The $K_{\mathrm{d}}$ of this protein was markedly higher than that of microbial thiamine-binding protein (E. coli: $9.2-50 \mathrm{~nm}$, S. cerevisiae: $29 \mathrm{~nm}$ and L. casei: $10 \mathrm{~nm}$ ), whereas its value was similar to the $K_{\mathrm{d}}$ value $(0.3 \mu \mathrm{M})$ of thiamine-binding protein isolated from egg white (8). Calculation from the molecular weight of 94,000 obtained by gel filtration on Sephadex G-200 and the $B_{\max }$ of $17.2 \mathrm{nmol} / \mathrm{mg}$ of protein, revealed the binding of $1.62 \mathrm{~mol}$ of thiamine per mol of the thiamine-binding protein. Furthermore, it was presumed that each subunit of rice bran thiamine-binding protein composed of two identical subunits ( $\mathrm{Mr} 50,000)$ binds one molecule of thiamine when the $B_{\max }$ obtained above was corrected to $19.1 \mathrm{nmol} / \mathrm{mg}$ of protein at optimal $\mathrm{pH}$.

The binding activity of thiamine-binding proteins from microorganisms was generally inhibited by thiamine phosphates and many other thiamine analogs. On the other hand, the binding activity of the thiamine-binding protein from rice bran to $\left[{ }^{14} \mathrm{C}\right]$ thiamine was not markedly inhibited by thiamine phosphates and thiamine analogs except for chloroethylthiamine. In fact, the affinity of the thiamine-binding 
Table 3. Binding of $\left[{ }^{14} \mathrm{C}\right]$ thiamine, $\left[{ }^{14} \mathrm{C}\right]$ thiamine monophosphate and $\left[{ }^{14} \mathrm{C}\right]$ thiamine pyrophosphate to rice bran thiamine-binding protein.

Each value is the average of duplicate determinations.

\begin{tabular}{lc}
\hline \multicolumn{1}{c}{ Substrate tested } & Binding $(\%)$ \\
\hline$\left[{ }^{14} \mathrm{C}\right]$ Thiamine & 100 \\
{$\left[{ }^{14} \mathrm{C}\right]$ Thiamine monophosphate } & 4.9 \\
{$\left[{ }^{14} \mathrm{C}\right]$ Thiamine pyrophosphate } & 0 \\
\hline
\end{tabular}

protein to thiamine phosphates was much less than that of thiamine. These results indicate that the thiamine-binding protein from rice bran is highly specific to the thiamine molecule. Furthermore, the strong inhibitory effect of chloroethylthiamine on thiamine binding is attributable to the similarity of the electronegativity between the oxygen atom and the chlorine atom in the thiamine structure. The specificity to thiamine of the protein may be particularly interesting since thiamine present in the free form in rice bran differed from the coenzyme form found in microorganisms and animal tissues. Although it is unknown whether all of the thiamine in rice bran is in the bound-form with the binding protein, the amount of the binding protein in rice bran is roughly estimated to be sufficient to bind most of the free thiamine present in rice bran.

Although the biological function of thiamine-binding protein in rice bran is unknown at present, roles both for retaining thiamine which is essential for germination and growth of rice and for supplying it to the endosperm when necessary should be considered.

We wish to thank Dr. A. Nishino and Dr. H. Nishino of our laboratory for participation in the initial stages of this study.

\section{REFERENCES}

1) Nishimune, T., and Hayashi, R. (1971): Thiamine-binding protein and thiamine uptake by Escherichia coli. Biochim. Biophys. Acta, 244, 573-583.

2) Iwashima, A., Matsuura, A., and Nose, Y. (1971): Thiamine-binding protein of Escherichia coli. J. Bacteriol., 108, 1419-1421.

3) Griffith, T. W., and Leach, F. R. (1973): The effect of osmotic shock on vitamine transport in Escherichia coli. Arch. Biochem. Biophys., 159, 658-663.

4) Henderson, G. B., Zevely, E. M., Kadner, R. J., and Huennekens, F. M. (1977): The folate and thiamine transport proteins of Lactobacillus casei. J. Supramol. Struct., 6 , 239-247.

5) Iwashima, A., and Nishimura, H. (1979): Isolation of a thiamine-binding protein from Saccharomyces cerevisiae. Biochim. Biophys. Acta, 577, 217-220.

6) Iwashima, A., Nishimura, H., and Nose, Y. (1979): Soluble and membrane-bound thiamine-binding proteins from Saccharomyces cerevisiae. Biochim. Biophys. Acta, 557, $460-468$. 
7) Kadner, R. J. (1978): Transport of vitamins and antibiotics, in Bacterial Transport, ed. by Rosen, B. P., Marcel Dekker, Inc., New York, pp. 463-493.

8) Muniyappa, K., and Agida, P. R. (1979): Isolation and characterization of thiaminebinding protein from chicken egg white. Biochem. J., 177, 887-894.

9) Muniyappa, K., Murthy, U. S., and Agida, P. R. (1978): Estrogen induction of thiamine carrier protein in chicken liver. J. Steroid Biochem., 9, 888.

10) Nishino, A., Nishino, H., and Iwashima, A. (1980): Presence of a thiamine-binding protein in rice bran. J. Nutr. Sci. Vitaminol., 26, 415-418.

11) Matsukawa, K., Hirano, H., and Yurugi, S. (1970): Preparation of thiamine derivative and analogs. Methods Enzymol., 18A, 141-162.

12) Iwashima, A., Matsuura, A., and Nose, Y. (1971): Thiamine-binding protein of Escherichia coli. J. Bacteriol., 108, 1419-1421.

13) Andrews, P. (1965): The gel-filtration behaviour of proteins related to their molecular weights over a wide range. Biochem. J., 96, 595-606.

14) Weber, K., and Osborn, M. (1969): The reliability of molecular weight determinations by dodecyl sulfate-polyacrylamide gel electrophoresis. J. Biol. Chem., 244, 4406-4412.

15) Lowry, O. H., Rosebrough, N. J., Farr, A. L., and Randall, R. J. (1951): Protein measurement with the Folin phenol reagent. J. Biol. Chem., 193, 265-275.

16) Matsuura, A., Iwashima, A., and Nose, Y. (1973): Purification of thiamine-binding protein from Escherichia coli by affinity chromatography. Biochem. Biophys. Res. Commun., 51, 241-246.

17) Nishino, A. (1976): Some properties of thiamine-binding protein of Escherichia coli. Vitamins (in Japanese), 50, 365-370.

18) Wilkinson, G. N. (1961): Statistical estimation in enzyme kinetics. Biochem. J., 80, 324331. 